\title{
PRESIDENT'S REPORT 2019
}

Committee Changes: The IMS committee had a change of both President and Vice President in 2019, with S. Buckley (MU) being replaced as President by P. Mellon (UCD), and P. Mellon being replaced as Vice-President by T. Carroll (UCC). Many thanks to the outgoing President for his excellent and wide-ranging work in this role and, in particular, for bringing the EMS Meeting of Presidents to Ireland in April 2018. We are grateful that S. Buckley opted to remain on the committee. I would also like to welcome T. Carroll to the committee and to thank J. Gleeson (UL) who left the committee after six years of dedicated work to the Society.

IMS Bulletin: This was a watershed year as the Bulletin moved to electronic format. This decision was communicated to members and to those institutions with whom the Society has exchange or reciprocity agreements. The Edinburgh Mathematical Society responded that they were actively considering making the same decision. Individuals may order a printed copy of the Bulletin for a small fee online. For archiving purposes the Editor has agreed to send printed copies to the small number of copyright libraries. I extend the Society's continuing thanks to A. O'Farrell for his work as Editor of the Bulletin and I also thank the editorial board of the Bulletin. We are grateful also to Michael Mackey for his considerable work in streamlining the Society's webpages.

IMS-LMS Reciprocity Agreement: Many thanks to M. Mathieu for acting as liaison with the London Mathematical Society and securing a unique IMS-LMS Reciprocity Agreement, which as a legal agreement was signed by the Presidents of both societies in June 2019 and came into effect in July 2019.

IMS meetings: The Society's 2019 annual "September Meeting" was held on September 5-6 in Galway and we thank NUIG and the local organisers, namely, A. Carneval, M. Destrade, G. Pfeiffer and R. Quinlan for their work in making this meeting a success. The AGM of the Society was held during this time, with six committee members being elected or re-elected, of whom, D. Malone will remain on as Secretary and Cónall Kelly (UCC) will be the incoming Treasurer. I'm delighted to announce that Dublin City University have agreed to host the 2020 annual conference on August $27-28$.

On December 6 Sligo IT hosted the Society's 4th Annual IMS Christmas Lecture given by Alastair Wood (Emeritus DCU). Alastair travelled from France to lecture on George Gabriel Stokes Life, Science and Faith. The lecture celebrated the 200th anniversary of the birth of the renowned Sligo mathematician. The Society's December committee meeting was held afterwards. Thanks to Leo Creedon, Kieran Hughes and Sligo IT for support.

IMS Conference Support: The Society supported the following conferences in 2019:

1. Analysis, Geometry and Algebra, TCD, May 8-11, 2019.

2. Groups in Galway, May 10-11, 2019.

3. Linear Algebra and Matrix Conference, May 23-24, 2019.

4. Irish Geometry Conference May 16-17, 2019. 
Thanks to our treasurer, G. Pfeiffer, for overseeing our Conference Support Scheme and keeping our finances in a healthy condition.

Other: The EMS meeting of Presidents was held this year in TU Berlin on March 23-24, 2019 and, as I unfortunately could not attend, Stephen Buckley kindly represented the Society instead.

I thank J. Grannell (UCC) for making an excellent proposal to the NCCA on behalf of the Society, regarding updating the Leaving Certificate Applied Mathematics course. The recommendations in the proposal were largely adopted and the new course creates many opportunities for students in a wide range of subjects.

To finish I want to pay the Society's particular thanks to a late, great friend of the IMS, Richard Timoney, RIP, who tragically passed away on New Year's Day 2019. Apart from serving as Secretary, Vice President and President of the Society, Richard set up and maintained our Society's webpages until just before his death. He is sadly missed.

E-mail address: pauline.mellon@ucd.ie

Pauline Mellon

December 2019 